\title{
AHPによる重要度評価を用いた部材選定方法及び修繥計画策定手法 に関する研究 \\ A STUDY ON MATERIAL SELECTION METHOD AND REPAIR PLAN METHOD WITH NECESSITY EVALUATION BY AHP
}

\author{
守谷謙一*, 近江 隆**, 石坂公一*** \\ Kenichi MORIYA, Takashi OMI and Koichi ISHIZAKA
}

\begin{abstract}
We analyzed judgement of building utility performance with physical, social, functional element of buildings.
The following point became obvious.

1. At present repair plan is rational, for close to an optimal repair-plan.

2. It needs to maintain it more briskly than a standard repair plan, to raise the rationality of a repair-plan in an architecture main body.

3. It is ideal to make a little maintenance-cycle long than it's standard, to raise the rationality of a repair-plan in equipment.

$4 \mathrm{It}$ is necessary to measure long-life-ization of a building from an administrative face, to improve a long-term effect in equipment.
\end{abstract}

Keywords: Life Cycle Cost, Analitic Hierarchy Process, Generic Algorithm, Building Repair Plan, Business Building ライフサイクルコスト,AHP, 遺伝的アルゴリズム, ビル修縉計画, オフィスビル

1 はじめに

\section{1. 背景}

近年、我が国経済の成熟化にともない、高度経済成長期に建設さ れた膨大な建物に対する維持管理・機能更新需要が增大してきてい る。また、良好な社会資本の蓄積、地球環境の保全等に関する社会 的要請の高まりを背景として、建築のロングライフ化の実現が強く 求められている。スクラップ\&ビルドの時代は終わりストック対策 が中心となる時代に入りつつあると言えよう。このような社会的要 請に対処するためには、建築の企画・設計から建設、維持保全、廃 㶳、再利用に至る建物の全ライフサイクルにわたる総合的な検討を 行う LCC (Life Cycle Cost)分析の考え方を積極的に遵入すること が重要になってきている。

建築物を対象とした LCC 分析は、従来のように㓍工時点のみの 性能を重視するのではなく、建物の全生涯にわたって建物がその機 能・性能を十分に発揮できるように企画・設計から施工・維持管理 の各段階で適切な方策を講じるとともに、社会情勢の変化に対する 可能な限りの対応策をも建設企画段階において総合的に織り込もう とする概念であると考えられる。

建物の LCC 分析に関寸る既往の研究を見ると、石塚 1 で LCC 算 定モデルの定式化が提案されて以来、LCC 分析に関する研究は多数
見られる 2) 3)4が、それらのほとんどは実際の資料をもとに維持管理 方式が建物の寿命・コストにどれだけ影響を与えるかを実証的に明 らかにしたものであると言える。LCC 分析を実際の建設・維持管理 計画の立案に適用していく場合には、何らかの意味で「最適」とい う概念を導入したうえで計画を立案することが必要である。しかし、 既往の研究の中にはこのような「戦略的視点」に立って維持管理方 式の選択や建物部材及び設備の耐用年数の選択等を初期コスト・維 持管理コストとの関係から分析した研究はあまり見られない。

\section{2. 研究の目的}

本稿では LCC 分析を実際の建設・維持管理計画に適用するため の手法の開発を目指し、建物の劣化・修繥過程に関する基本的なモ デルを設定した上で、これに遺伝的アルゴリズムを適用することで、 適切な計画を立案する手法を提案することを目的としている。

遺伝的アルゴリズムは、建築分野においてもいくつかの研究 5) 6) において用いられているが、LCCに関して用いられた例はあまり見 られない。遺伝的アルゴリズムは多数の選択肢の中から最適な組み 合わせを選択する際に有効な手段であり、多数の修繥計画の組み合 わせからなる LCC 計画の立案にも有効であると考えられる。

そこで、本稿では建物の様々な部材に対応可能な劣化・修繥の数 学的モデルを作成し、それに対する最適修繒計画を導く方法につい

\footnotetext{
* 自治省消防宁予防課 工博

** 東北大学大学院工学研究科都市建築学専攻 教授. 工博

*** 東北大学大学院工学研究科都市建築学専攻 助教授・工博
}

Fire and Disaster Management Agency, Ph. D. (Eng.)

Prof., Dept. of Architecture, Tohoku Univ., Dr. Eng.

Assoc. Prof., Dept. of Architecture, Tohoku Univ., Dr. Eng. 
て検討する。

本稿は文献 》を基としてその発展を図ったものである。文献 》で は、建物全体を一つの部材と見なし、それに対する LCC 評価の最 適化を図る手法を提案したが、本稿では多部材で構成された建物を 対象とした場合にも LCC 評価が可能となるようにモデルを㧪張し ている。そのために、各部材ごとの重要度の差異をアンケート調㚗 のデータをベースとして、AHP (Analiric Hierarchy Process：階 層化意志決定法）によって求めた。また建物の建設時の各部位にお ける材料についても複数の候補から選択することを想定し、より一 般的な部材選定計画の立絮のための方法を検討した。

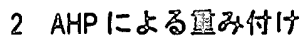

2.1. AHP

AHP7は、アメリカの Saaty 教授が提唱し、現在広く応用されて いる不確定な状況や多様な評価基淮における意志決定手法の一つで あり、その手順は次のようである。

曰）複雑な問題を評価目的、評価構造と代替案によって階層棬造 に分解し、階層図を害く。

b）階層の各レベルの要素をすぐ上のレベルの要素（評価基淮） を視点として、一対比較し、人間の定性的判断を定舅化する 尺度によって、一対比較行列を作る。

c）各一対比較行列の固有ベクトルの計算とその整合性評価指数 の検定及びウェートの合成を通じて、評価結果としての総合 ウェートを得る。

2.2. 本制にふけるAHP そデル

\section{(1) 上位項目}

本稿における AHP のモデルは、建築、設備それぞれについて文 献 18)で定式化されている劣化の 3 要因、すなわち破損や污損などの 「物理的な性能の劣化小、居住性やユーザーニーズへの対応性、デザ インの陳腐化といった「機能的な劣化小、用途の変更や周辺環境の変 化に対する経営方針の変更や収支の悪化などの「社会的な要因」を 修縜の意志決定要因における上位項目として設定した。

(2) 中位项目

中位項目としては、上位項目の場合と同様に文献 16)で各劣化の内 容として定式化されているものを設定した。すなわち、物理的要因 としては、部材が壊れて使えない状況である「物理劣化小、使用には 图らないが外筧を損的る「污れ」の二項目を、機能的要园としては、 レイアウト变更や新規設備納入場所のなどに対する「利便性の悪化小、 騷音や狭㿽感といった「快適性」デザインの流行遅れなどの「陳府 化小、社会的要因としては、維持管理瞢用の増大、収支の悪化などの 「罍用」、用途変更や環境変化への対応といった「経営方針の变更」 である。

(3) 代敏察

代替案としては、立献 1で述べられている建物の各部材のうち、 建物管理者へのアンケート調笪結果をデータとして用いることを考 愿し、使用者にとって日常的な劣化認識の対象となる部分として、 各中位項目ごとに建筑では外壁、内壁、天井、偞、建具、設備では 照明、通信、給排水、空調、搬送機を設定した。

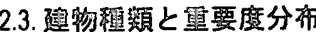

(1) 分析诗毁

分析は 1997 年に仙台市内のオフィスビル。商業ビルのうちから 住宅地図をべースに無作為に抽出した 300 槙のビルについて、管理 者に対して行ったアンケート結果をもとにした。

アンケートは、郵送と戸別訪問によって行い、有効回収数 107 通 を得た。その概要は表 1 に示すとおりである。なお商業系。事務系 の区分は延へ床面櫝の過半を占的用途にしたがって分類している。

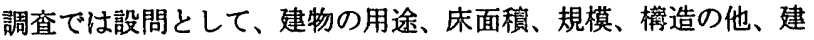
物を修繥する際に重視する部位及び留意する点を專ねた。特に建物 の重要度を分析するための設問は、物理的・機能的・社会的要因に ついての判断を一対比較によって行い、中位項目における部材間の 比較は各項目ごとに部材の重要度を 3 点から 0 点までの点数をつけ てもらうことによって行った。

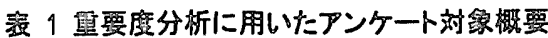

\begin{tabular}{|c|c|c|c|c|c|c|c|}
\hline & & 速毁年脌 & & & & & \\
\hline 角這 & 度面覆 & 1950 & 1960 & 1970 & 1980 & 1990 & 學结t \\
\hline 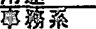 & $\sim 2999 \mathrm{~m}$ & & 3 & 12 & 5 & 3 & 23 \\
\hline & $3000 \sim 5999 \mathrm{~m}^{\circ}$ & & 8 & 8 & 8 & 6 & 31 \\
\hline & $6000 \mathrm{~m} \sim$ & 3 & 3 & 8 & 6 & 5 & 25 \\
\hline 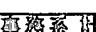 & 栾胎人 & $\frac{1}{4}$ & 14 & 29 & $\frac{1}{20}$ & $\frac{1}{15}$ & $\frac{3}{82}$ \\
\hline 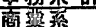 & $\sim 2999 \mathrm{~m}$ & & & 3 & 3 & & $\frac{06}{6}$ \\
\hline & $3000 \sim 5999 \mathrm{~m}^{\circ}$ & & & 5 & 4 & 1 & 10 \\
\hline & $6000 \mathrm{~m} \sim$ & & 1 & 3 & 3 & 1 & 8 \\
\hline & 媇把入 & & & & 1 & & \\
\hline 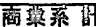 & & & 1 & 11 & 11 & 2 & 25 \\
\hline 给标 & & 4 & 15 & 40 & 31 & 17 & 107 \\
\hline
\end{tabular}

\section{(2) 画要庣分布}

アンケート調査の結果から、建築、設備それぞれについて、AHP により上位項目、中位項目、代替案の各段階における重要度を解析 した。107 件の回答について、全体を一括したもの、用途別 2 区分(業 務用・事務用)、延へ床面䅐による規模別 3 区分( $3000 \mathrm{~m}^{2}$ 未満、3000 $\sim 6000 \mathrm{~m}^{2}$ 未満、6000 $\mathrm{m}^{2}$ 以上)、規模別 2 区分 $\left(6000 \mathrm{~m}^{2}\right.$ 未満、6000 m以上)の場合についてそれぞれ重要度を求め、AIC (Akaike Information Criterion）を用いて有効な区分方法を検討した結果 （表 2）、規模を 2 区分して分析することが最も適切であり、つい で全体を一括して取り扱うことが適切であることが判明したので、 以降の分析では規模別に中小規模（延べ床面䅡 $6000 \mathrm{~m}^{2}$ 未満）と大 規模（延べ床面䅐 $6000 \mathrm{~m}^{2}$ 以上）に分けて検討を行うこととした。

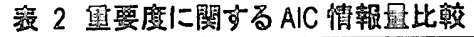

\begin{tabular}{|c|c|c|c|}
\hline \multicolumn{2}{|c|}{ 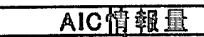 } & 建爱 & 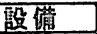 \\
\hline 至傸 & - & 341.95 & 340.56 \\
\hline 营颔別 & 2玉分 & 349.82 & 348.39 \\
\hline 親䍒別 & 3区分 & 344.97 & 343.56 \\
\hline & 2巨分 & 337.00 & 335.60 \\
\hline
\end{tabular}

図 1に示すのは、規模別(2区分)で見た場合の建築、設備の重要 度分布である。

建築本体の物理的要因で重視されたのは外壁で、使用者の目に触 れやすいことから重視されたと考えられる。また、機能的要因から 重視されたのは、床、天井であり、利便性を高めるために天井や床 の機能的配置が考鼒された結果であると思われる。社会的要因から は、外壁・建具が重視される傾向があり、デザインの陳應化などが 目立つ部分であることによると考えられる。また規模に関わらず内 壁、昇降機に対する重要度は低い。これは、これらの項目が社会的 要因として作用寸る面が少なく、また物理的・機能的要因において もあまり重視されない傾向があることによるものと思われる。 

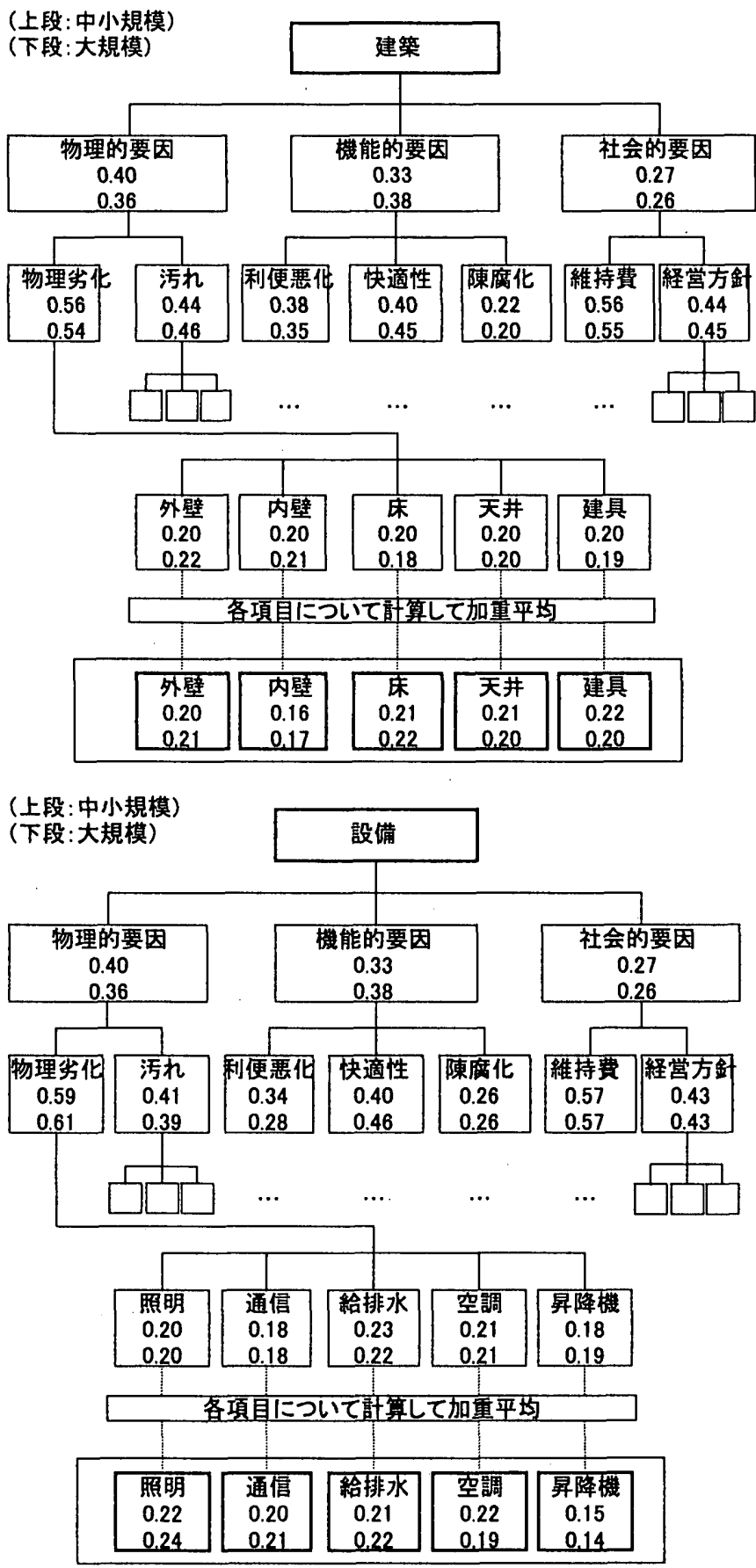

図 1 各部位の重要度分布(上段·建築本体、下段·設備部分)

規模による差異をみると、大規模のビルでは床、内外壁の重要度 が高く、中小規模のビルでは天井、建具の重要度が高くなっている。 上位項目における差異をみると、大規模の場合は機能的要因を重視 する傾向が強いが、中小規模の場合は物理的要因を重視する傾向が 強い。代替案での重要度は上位・中位項目の重要度をも考慮した加 重平均值として得られているので、この結果は、大規模の場合には 使い勝手を重視し、中小規模の場合には物理的な劣化を重視すると いう傾向を反映したものであるといえる。

設備の物理的要因で重視されるのは通信、空調の各部位で、これ らの部位は使用者が日常的な使用頻度が高いために劣化が感じられ やすいことに起因していると考えられる。機能的要因から重視され

たのは、通信、空調、照明である。設備の各部位はやはり日常的な 使用頻度が高いために更新・修繥作業が行われることが重要視され る原因であると考えられる。また、社会的要因からは各部位間に重 要度の差があまりみられなかった。

規模別に差異が見られる点については、大規模では照明を重視し、 中小規模では空調を重視する傾向が見られる。照明の重視は、維持 管理費、利便性の各項目が重視されることによることから、大規模 な建物では照明の規模が大きくなることによる電気負荷の軽減や照 明レベルの部分調整などが必要とされていることがうかがえる。空 調には維持管理費の項目が大きな比重を占めているが、中小規模の 場合にセントラル空調からユニット空調に切り替えることによる管 理費用の軽減に関心が集まっていることに対応していると思われる。 3 最適部材選定の方法

3.1. 劣化のモデル

(1) 対象

基本的なモデルの対象を本論文では「部材」と称することにし、 部材は「躯体」「外装仕上げ」といった『部位』と、「タイルによる 仕上げ」「アクリル系塗料による仕上げ」といった『材料』によって 構成されるものと考える。なお、対象となる建物はオフィス・商業 系を想定している。

また、LCC では建物の生涯の運用に対する評価をおこなうが、こ こでは建物の生涯にかかうた総費用に対する得られる総収入の比に 相当するものを評価指標として用いることとする。

(2) モテルの概念

ここで、部材モデル作成に際して最も基本的な部分である評価関 数、部材性能関数を概念的に説明する。

\section{(1) 評価関数}

評価関数の值は、部材の物理的性能(P:Performance)、部材にか かる費用(C: Cost)によって構成されると考えられるが、その具体的 な形は経営的な判断によって決定されると考えることができる。経 営的判断の結果としての物理的性能の評価は、社会的要因や経済的 要因によって規定され、物理的性能そのものではないことが一般的 であろう。ここでは、社会・経済的要因をも考慮した経営的判断の 結果としての物理的性能の評価值を「効用」(U : Utility)と呼ぶこと とし、建物から得られる賃料に相当すると考える。ここではその評 価関数として、「效用」を「費用」で割ったものU/C を考え、これ を費用対効用( Value Index : VI ) と呼ぶこととする。

\section{(2) 物理的性能}

物理的性能 $(\mathrm{P}(\mathrm{t}))$ は、修繥を行わない場合には時間の経過にともな って低下、すなわち劣化するものとする。この自然な劣化に対して、 経営期間中に満足な性能を保持するために修䋨を行うが、修繥量を 時間軸に沿って並べた関数が修繥計画となる。

\section{2. モデルにおける各関数の展開}

\section{(1) 物理的性能}

劣化は、部材の設置からの時間 $(\mathrm{t})$ に関する性能値 $(\mathrm{P}(\mathrm{t}))$ によっ て『劣化曲線』としてあらわす。劣化曲線は $P(0)=P_{0} 、 P\left(T_{1}\right)=P_{1}$ $\left(P_{0}>P_{1}\right) 、 0 \leqq \mathrm{t} \leqq \mathrm{T}_{1}$ の全域にわたって $\frac{d P(t)}{d t}<0$ である。劣化 曲線としては種々の単調减少関数が考えられるが、劣化パターンを 


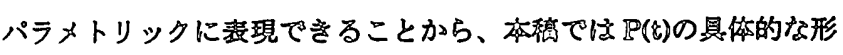

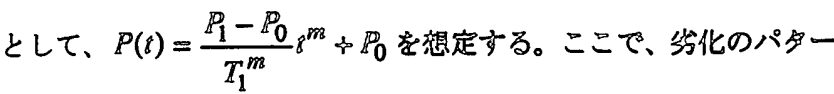

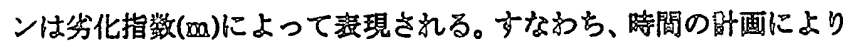

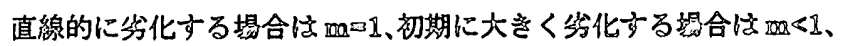

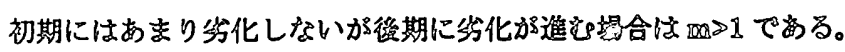

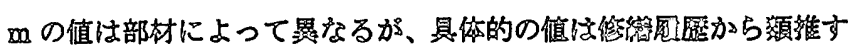

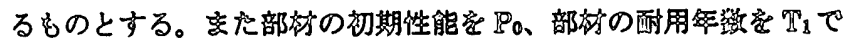

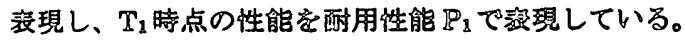

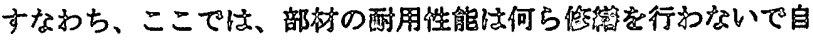

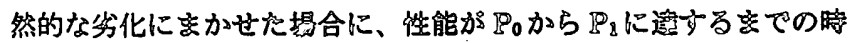
間として定娹している。

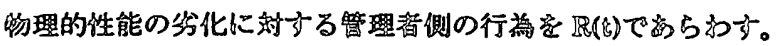

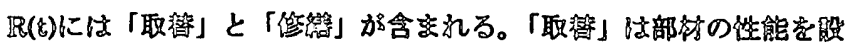

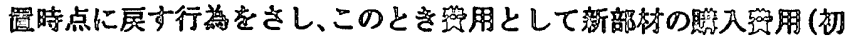

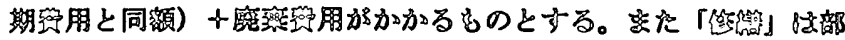

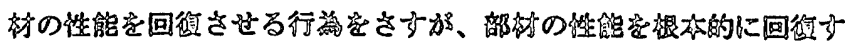

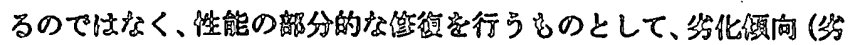

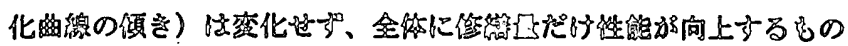

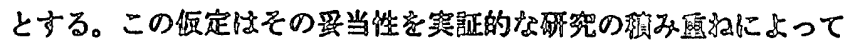

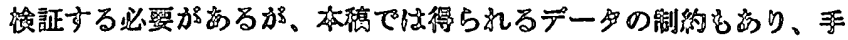

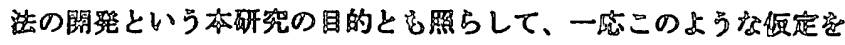
おくこととした。

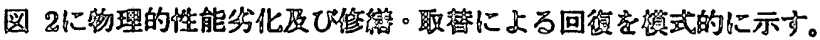

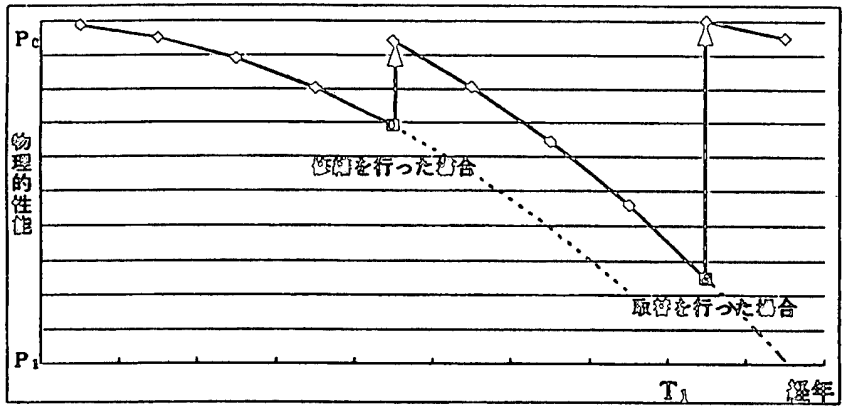

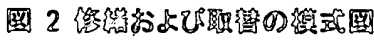

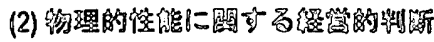

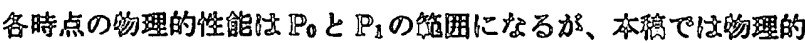

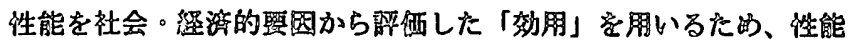
を勃用に变旗する必票がある。

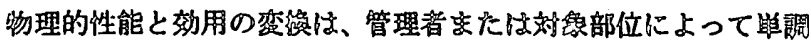

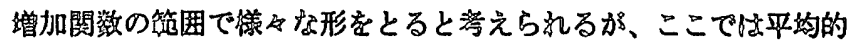

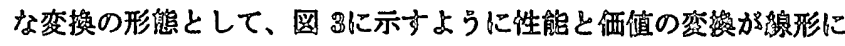
行われるものと仮定した。

式であらわすと、時点しに活ける效用は炏式となる。

$$
U(\ell)=U_{0} \frac{\mathbb{P}(8)-\mathbb{P}_{0}}{\mathbb{P}_{0}-\mathbb{P}_{a}}
$$

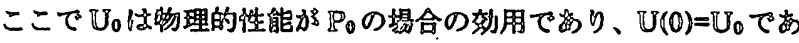

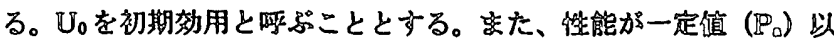

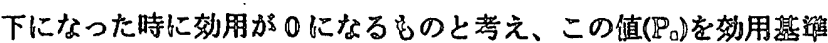
值と呼ひ、、経営圭体の部猚の物理的な性能に封らる脬価を反映する
ஆのとした。ここで然然

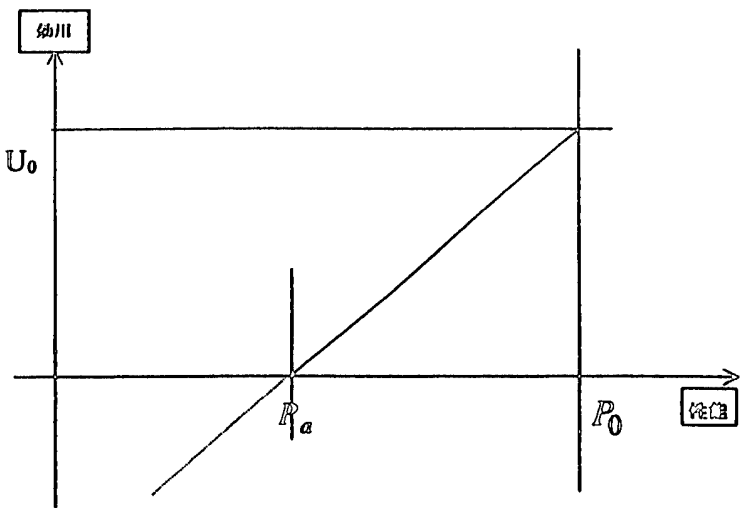

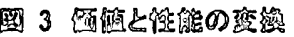

(3) 经周

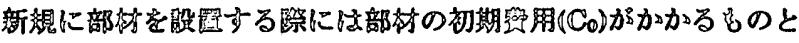

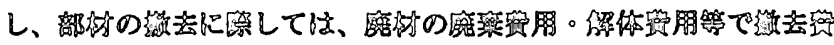

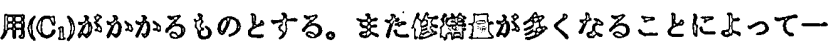

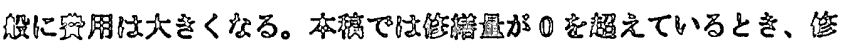

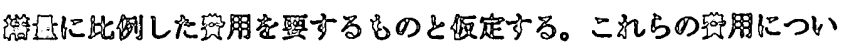

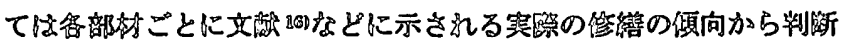
して䛇定学行う。

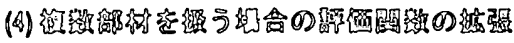

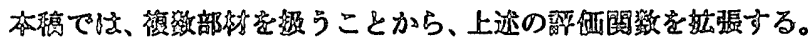

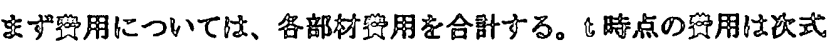
で劣らわされる。

$$
C(8)=\sum_{i=1}^{1} C_{i}(8) \quad \dot{B}: \text { 部彷 } \quad(i=\mathbb{1} \sim \mathbb{Z})
$$

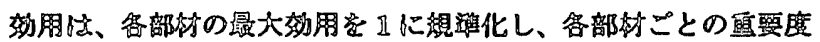

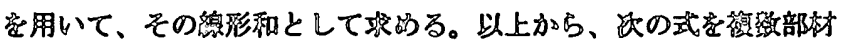

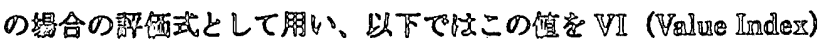
で部らする。

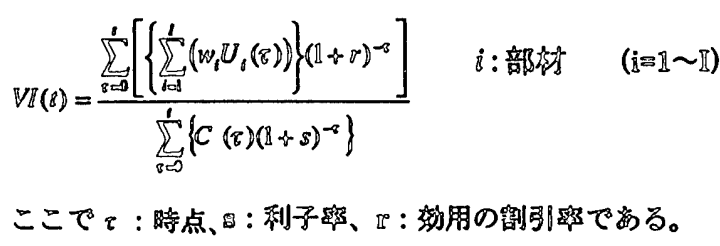

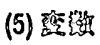

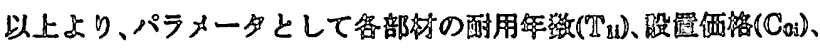

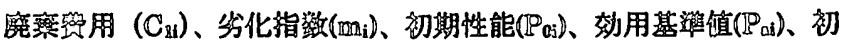

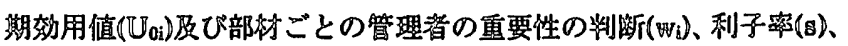

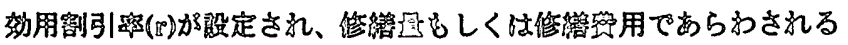

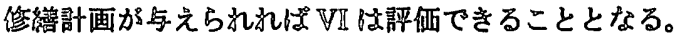

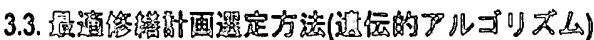

(1) 擝念

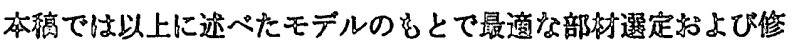
筑計画を筑出らることを目的としている。

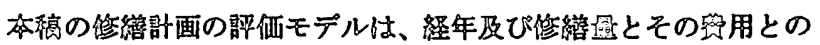
閶係によって表現することか゚できる。こうした評俳テデルの最大化 には、一般に最適制御の方法が用いられる。 
しかしながら、本稿のモデルでは(1)性能の上限・下限が制限され ることによる不等式制約がかかるために数理的解を求めることが困 難であり、(2)取り替えが生じる際に費用と修縉量の関係が不定にな ることから、現在一般的に行われる数理的方法の適用が困難である 9)。一般に用いられる変分法では、複雑な不等式制約のかかる問題 はダミー変数を用いて等式制約に置き換えて解析解を求める。しか しながら、その計算には複雑な定式化が必要であり、本稿では実際 の計画に適用する場合における簡便性と計算時間の短縮を図る目的 から、シミュレーションによる探索を検討することとする。

本稿では、離散化した $\mathrm{R}(\mathrm{t})$ に対するシミュレーションを行うこと で修繥計画を求める。 $\mathrm{R}(\mathrm{t})$ を $\mathrm{n}$ 段階の離散的な值をとるものとし、 部材数(I)、経営期間 $(\mathrm{A})$ における全部の修繥レベルについてのシミュ レーションを行うと $\mathrm{n}$ (A)回の計算が必要となり、一般的な場合には 実用的な時間範囲内において結果を得ることが非常に困難である。

そこで、より少ない試行によって最適な修繥計画を行うためのア ルゴリズムとして、遺伝的アルゴリズムによる解法を提案する。

(2) 迩伝的アルゴリズム

遺伝的アルゴリズム(GA: Generic Algorithm)とは、生物の形態・ 形質が遺伝子により進化する過程を模做したアルゴリズムである 10)。 本稿では各パラメータを次のように設定した。

1. 本稿では各年における建設時の部材選択及び取替・交換を含 む修縉計画 $(\mathrm{R}(\mathrm{t}))$ を遺伝子とし、それを部材数 $\times$ 経営期間分、 並列したものを染色体とする。

2. 染色体の環境への適合度はVIによって評価する。

3. 交叉は一点交叉とし、突然変異を遺伝子ごとに $10 \%$ 確率で 生じるものとする。

(3) 遗伝子の構成

本稿の遺伝子は、以下の 0 12 の值をとるものとする。 0 : 修繥しない

1〜10：修縉量が 0.1〜1.0の修繥を行う。

11 : 標準部材に取り替える。

12 : 部材を標淮部材と同じ初期性能・耐用性能を持ち、劣化指数 $\mathrm{m}$ 、耐用年数 $\mathrm{T}_{1}$ が異なる他の部材（代替部材）に交換する。 ただし、R(0)は建設時における部材の選択をあらわす遺伝子であ り、值としては 11 または 12 のいずれかをとるものとしている。

\section{(4) 親染色体の選定}

子を作るための親の選定方法には、評価值を重視する方法やラン ダムに選択する方法などがあるが、今回は染色体の多様性の保持を 重視し、評価值によって親を 10 分割し、評価値の平均值が上位の グループから優先的に採用するように選定を行い、一時的に優秀な 一つの染色体のみが継承されて局所的最適値に陥る危険を回避した。 また収束性の向上のため、その世代までで最大のVI をもつ修繥計 画に関しては、常に親として含まれるものとした。

\section{(5) 遗伝的アルゴリスムの有効性}

遺伝的アルゴリズムの計算量はほほ(染色体数 $) \times($ 世代数 $) \times($ 染色 体長)に比例する。本稿では計算機凟源の制約も考慮して、染色体数 を200、世代数を 10000 とした。

図 4k、計算期間 8 年の場合について、全ての修繥計画の組み合 わせを計算した場合のVIの最大值を $100 \%$ とたときにGA を用い た場合の VI の最大值を示す。この場合は概小 2000 世代で最適值の
99\%の值が得られ、以降の変化はほとんどないことから、本稿で採 用したアルゴリズムは一応の有効性を持っているものと考えられる。

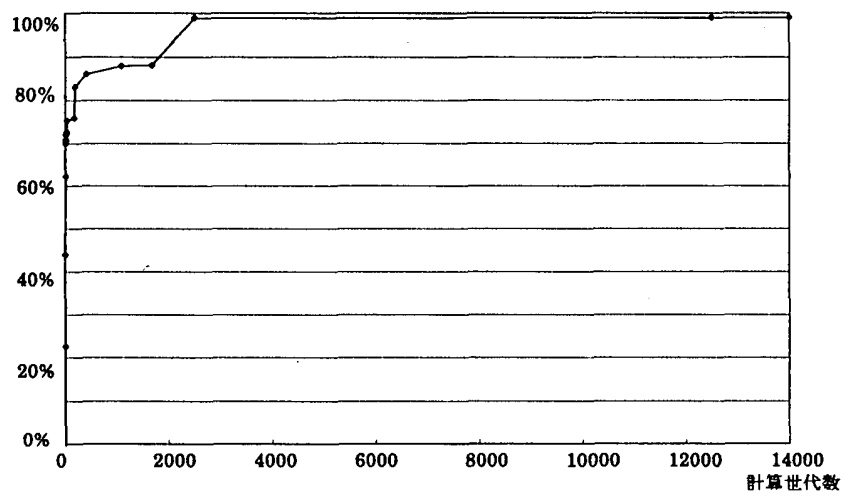

図 4 全数探索時のVIとGAのVIの比較

\section{4. 局所的最適化}

遺伝的アルゴリズムは、最適值付近までの収束は比較的早いが、 それ以降の最適値の探索効率は低下する性質があることが知られて いる。そのため、最適值の探索にあたっては遗伝的アルゴリズムと 他の局所的探索手法を組み合わせて用いることが一般に行われてい る。本稿では、遺伝的アルゴリズムによって算出された修䋹計画に ついて、その近傍においてよりよい評価となる修繥計画を探索する ため、次の手順に従って順次サーチを行った。

1. 各年次について、計画の変更を加えた場合の評価值を調へ、 それが変更前に比較して向上する場合、計画をその年次に限 って変更する。

2. 変更がなされた場合にはその計画をもとに絽り返し計画の変 更を行う。

3. 各年次の計画を変更しても評価值が向上しなくなるまで 1 2 を繰り返す。

局所最適化を行うことにより、遺伝的アルゴリズムの結果に比べて $5 \%$ 程度の改善効果が得られた。

4 各部材のパラメータ

4.1. 部位構成

表 3 モデル構成部材.

\begin{tabular}{|c|c|c|c|c|c|c|c|}
\hline & & 部值 & 树料 & & & 部伍 & 材料 \\
\hline 建栗 & 西体 & 楚筑 & 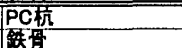 & 连案 & 内外蕀 & 曻擘 & 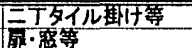 \\
\hline & & & ヨンクリート & & & 岸 & 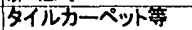 \\
\hline 碬满 & 基幹系 & 铚根 & アスファルト路出雲 & & & 丙檠 & 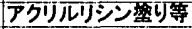 \\
\hline & & 電氮 & 配動盘 & & & 天并 & 化柱石毛ボート等 \\
\hline & & & 変压㗊 & 設满 & 端末系 & 照明 & 獣光奵 \\
\hline & & & キューピらル & & & 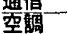 & 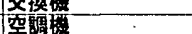 \\
\hline & & 垔䐓 & ホイラー & & & 路排水 & 䏩水口 \\
\hline & & & 命溥檴 & & & & 絡臎口 \\
\hline & & 給排永 & 受永槽 & & & & 为贡 \\
\hline & & & 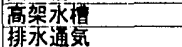 & & & 投送 & Iレヘーータ \\
\hline
\end{tabular}

建物を構成する部材について、文献 11)を参照して表 3に示すよう に部材の構成を行った。各種配管類についてはそれぞれの端末に含 まれるものと考える。

これらの部材について、文献 12)、13)等を用いて数量の予測を行う こととした。各種面積等の計算に当たっては、建物を直方体状の形 態であると想定して行った。 
1.延べ床面賴と階数を適宜想定する。

2. 階数から棈造方式（RC、SRC）を想定する。構造方式と延べ 床面䅡から铁骨量、コンクリート量を定める。

3. 延べ床面稳と階数から建築面穦を求める。建築面積は屋根面 櫝と対応する。

4. 建築面穞に従ってコア方式を求め、各種コア方式(中央コア、 片側コア、両端コア)の標淮的な幅から幅と奥行きを求める。

5. 標準的な階高（荏贷ビルで 3.556m）と幅・奥行きから建物全 面の壁面䅡、正面方向の壁面䅡を求める。これらの面䅐は外 壁、建具面榎に対応する。

6. 建篡面䅡から柱数を想定する。ここでは柱スパンとして $8 \times$ 12m を標準として与えている。

7. オフィスの平均的居住人数を元にエレベータ数を想定する。

8.一般的な各設備の必要量を算定する。

\section{2. 洒施}

価格については、文献 11)を参照して各材料ごとに材工ともの费用 を求め、各部位において必要とする量と価格を垂じ、合算した金額 を直接工事费とした。

計算に用いた数毁の約 $2000 \mathrm{~m}^{2}$ の其ビルについての例を表 4 示 す。また文献 14),15)に揭载されているいくつかのビルについて延床面 程と階㢺から建築、設備营用を求め、実際の工事费と比較した。相 関係数は建築で 0.94、設備で 0.87 となり、概成整合しているとい える。

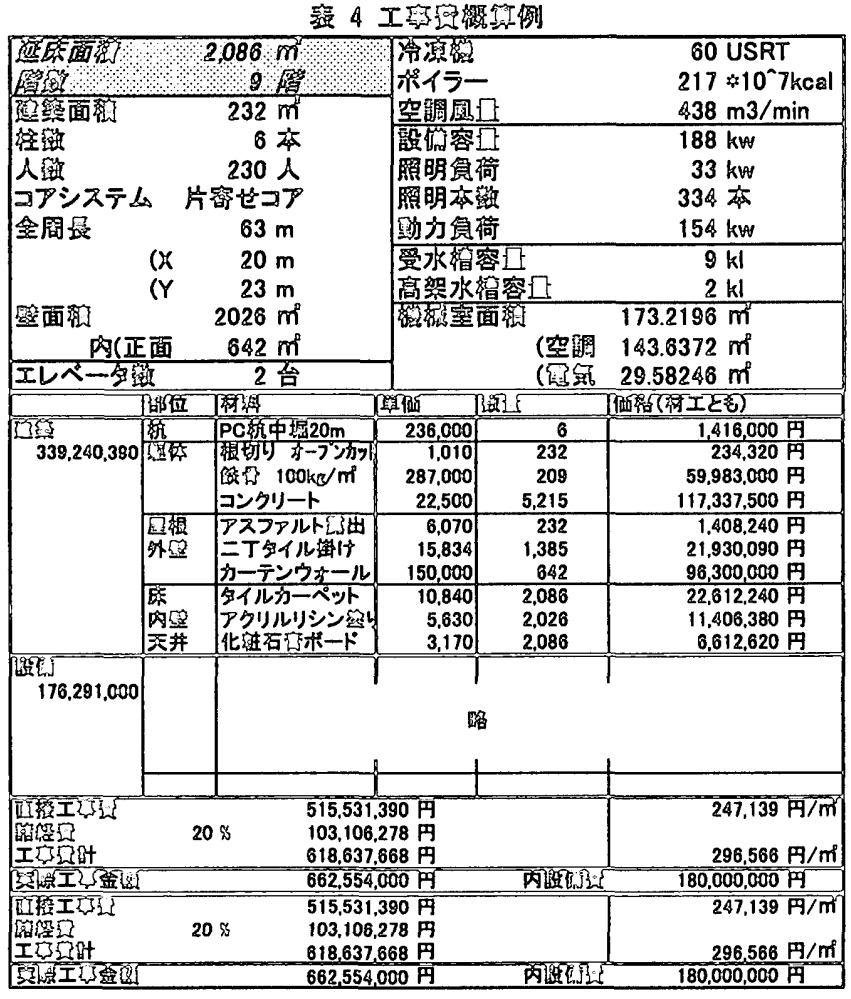

4.3. 行令と管化曲線

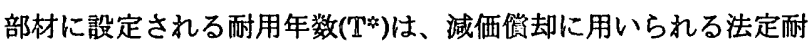
用年数、実際に使用している場所での交换経戨に基づいた計画更新 年数がある ${ }^{13)}$ 。本稿では、実際の使用状況に近い状態をモデル化す るため、計画更新年数を部材に設定される耐用年数( T中神)とみなした。
前述したように本稿で計算に用いる耐用年数 $\left(\mathrm{T}_{1}\right)$ は、修繥を行わ なかった場合に部材の性能が耐用性能 $\left(\boldsymbol{P}_{1}\right)$ に達する時点をさす。計

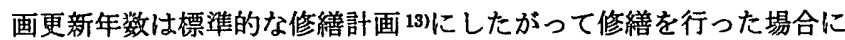
部材が耐用できる期間であるため、本稿の計算で用いる耐用年数と は異なっている。そこで、部材に定められた標準的な修缳計画(b(t)) と計画更新年数 $\left(T^{2}\right)$ から計算で用いる耐用年数 $\left(\mathrm{T}_{1}\right)$ お よび劣化指数 (m)を以下により算出した。

部材の劣化関数 $(\mathbb{P}(\mathrm{\imath}))$ は、初期性能 $\mathbb{P}_{0}$ を $\mathbb{P}_{0}=1$ 、耐用性能 $P_{1}$ を $\mathbb{P}_{1}=0$ となるように基淮化しても劣化指数 $\mathrm{m}$ 、耐用年数 $\mathrm{T}_{1}$ は変化せず、 一般性は失われないので、以下では $\mathbb{P}_{0}=1 、 \mathbb{P}_{1}=0$ と想定する。この 想定のもとではなにも修緗を行わない場合の、時点てにおける部材 の性能は $\mathbb{P}(\imath)=1$ - $\left(\boldsymbol{\tau} / \mathbb{T}_{1}\right)^{m}$ とあらわされる。時点 $\tau$ に修繥(修繥量 $b(\tau)$ : 修繥が行われなかった場合は $b(\tau)=0$ と考える)が行われた 場合には次式となる。

$$
P(t)=1-\left(t / T_{1}\right)^{m}+\sum_{\tau=0}^{t} b(\tau)
$$

したがって計画更新年数の定義から次式が成り立つ。

$$
\mathbb{P}\left(T^{*}\right)=1-\left(T^{*} / T_{1}\right)^{m}+\sum_{\tau=0}^{1} b(\tau)=0
$$

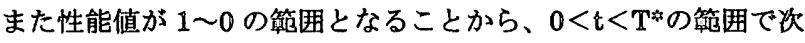
式が満足される必要がある。

$$
0<P(t)=1-\left(z / T_{1}\right)^{m}+\sum_{r=0}^{1} b(\tau)<1
$$

これらの式から $\mathrm{T}^{*}$ と $\mathrm{b}(\tau)$ がちられた場合の $\mathrm{T}_{1}$ と $\mathrm{m}$ について 上限值と下限値を算出し、 $\mathrm{T}_{1}$ が最も長くなるように $\mathrm{T}_{1} 、 \mathrm{~m}$ を定め た。

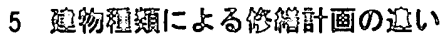

本稿では、中小規模のオフィスビルを $6000 \mathrm{~m}^{2}$ 圭満、大規模のも のを $6000 \mathrm{~m}^{2}$ 以上としているが、規模別の修繥計画について検討す るため、中小規模として $2500 \mathrm{~m}^{2} 9$ 階建て、大規模のものとして 9000 $\mathrm{m}^{2} 9$ 階建てのものを比較した。なお、利子率、効用割引率について はそれぞれ $2 \%$ とし、効用基淮值は標淮的な管理者に対する值とし て0を想定した。

以上の前提のもとで得られた最適な修繯計画について、標淮的な

\begin{tabular}{|c|c|c|c|c|c|c|c|}
\hline \multirow{2}{*}{ 中小规落(2500m) } & \multicolumn{7}{|c|}{ 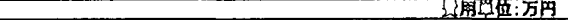 } \\
\hline & 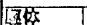 & 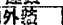 & 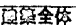 & 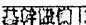 & 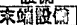 & & \\
\hline 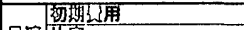 & 8.274 & 7,715 & 18.989 & 8,500 & 18,968 & 27,468 & 44.457 \\
\hline La过 & $55 \times$ & 458 & 1005 & 315 & 8095 & & \\
\hline 的证 LCCI用 & 10,238 & 26.683 & 38,920 & 64.632 & 70,287 & 134,918 & 171,840 \\
\hline 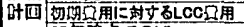 & 1100 & 34685 & $217 \pi$ & 7003 & 3715 & 4910 & 3875 \\
\hline 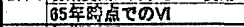 & 48.5 & 18.2 & 25.2 & 7.2 & 15.3 & 11.3 & 15.58 \\
\hline 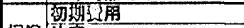 & 9.205 & 7,715 & 17,011 & 8.500 & 18.968 & 27,468 & 44,478 \\
\hline 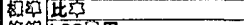 & $55 \mathrm{~N}$ & $45 \%$ & 1000 & 315 & 690 & 1000 & \\
\hline LCCI用 & 8,938 & 26,029 & 35,968 & 66,586 & 69,370 & 135,955 & 171,823 \\
\hline 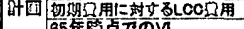 & 1075 & 3375 & 2115 & 7835 & 3665 & -4955 & $387 x$ \\
\hline 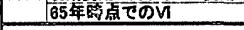 & 46.7 & 14.8 & 23.6 & 6.2 & 14.3 & 10.2 & \\
\hline 大规恕 $\left(9000 \mathrm{~m}^{\prime}\right)$ & & BE & & & 7 & & 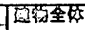 \\
\hline & & & 123661 & & & & \\
\hline 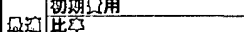 & $\frac{77.425}{6355}$ & $\frac{40.236}{3755}$ & $\frac{123,661}{100 \%}$ & $\frac{18,346}{2895}$ & 46,236 & 64,581 & 188,242 \\
\hline 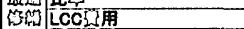 & 81.326 & 146,858 & 228,283 & 128.576 & 148,958 & 275.533 & 503.817 \\
\hline 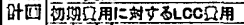 & 1055 & $318 x$ & 1858 & 7015 & 3189 & 4275 & 2685 \\
\hline 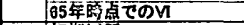 & 51.4 & 17.5 & 29.7 & 7.7 & 17.6 & 12.9 & 17.98 \\
\hline 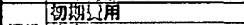 & 77,493 & 46.230 & 123,729 & 18,346 & 46,233 & 64,581 & 188,310 \\
\hline 0040 & $63 N$ & 378 & 1002 & 285 & 725 & $100 \%$ & \\
\hline 5 LCCD? & 79.540 & 148.989 & 228,528 & 133,281 & 148,989 & 282,270 & 510,799 \\
\hline 3 & $103 x$ & $322 \times$ & 185 & 7278 & $322 \pi$ & 4378 & 2711 \\
\hline 65年既 & 48.6 & 16.3 & 27.7 & 6.8 & 16.2 & 11.6 & 6.40 \\
\hline
\end{tabular}
修纁計画と比較したものを表 5 及び図 5、6に示す。

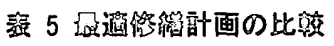




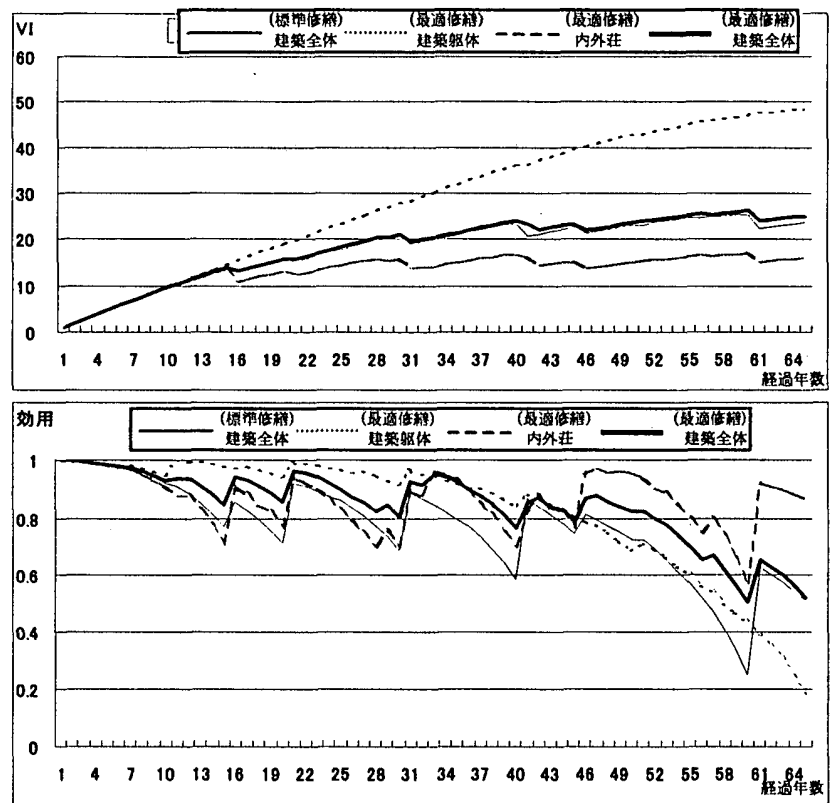

図 5 計画期間 65 年における中小規模建物・建築本体の修綪計画

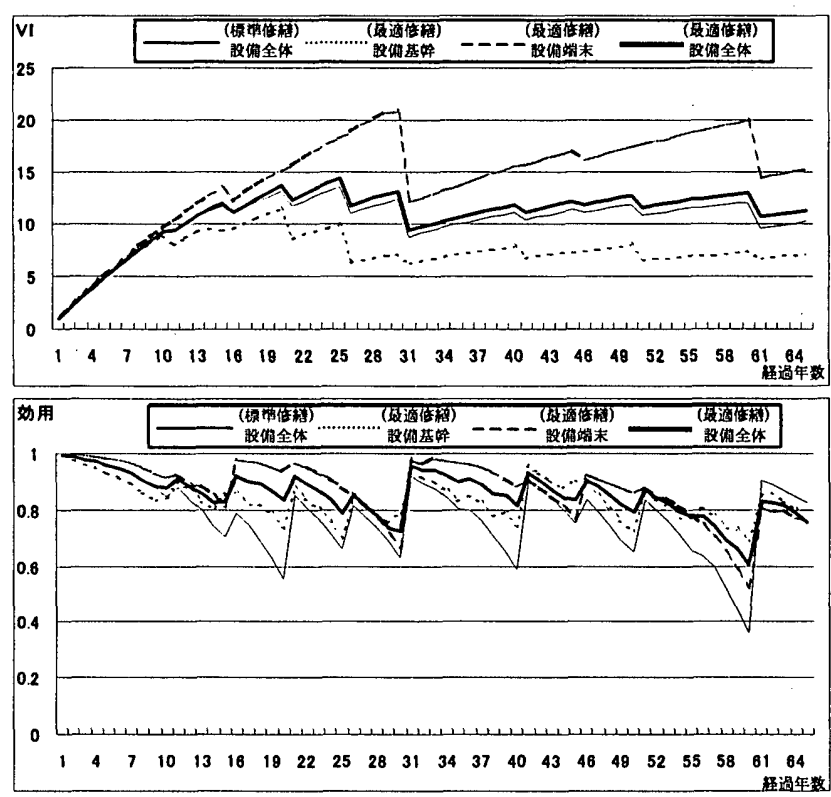

图 6 計画期間 65 年における中小規模建物·設備部分の修䋨計画

最適な修繥計画として計算された結果は、標準的な修繥計画にか なり近いものであり、現在行われている修繒が費用対効用(VI)の観 点からも妥当であることがわかる。

費用についてみると、初期費用については標準修繥計画と最適修 繥計画での差がほとんど見られないが、LCC 総額としては建筑では 最適修繥計画を行った場合の方が高くなり、設備では安くなる傾向 がある。これは建筑では標準修繥計画に比較してよりこまめに修繥 を行っているためであり、それによって効用の向上が図られている。 その結果、建築においては効用値の時系列に沿った変化は、標準修 䜌計画に比較して全体的に狭い範囲に収まり、過度の劣化を防ぐよ うな計画となっている。逆に設備では、標淮的な修繽計画よりも若 干修繥周期を長めにとることが合理的であるという結果が得られて おり、標淮修縉計画は十分な余裕をもったものとなっていることが
うかがえる。このため、修繥計画を若干粗くすることにより費用対 効用の向上が図られる可能性があるが、実際の運用にあたっては劣 化度に対する充分な検討が必要であると考えられる。

\section{1. 規模別}

規模別に比較すると、小規模のものの LCC 費用が高くなってい る。大規模建物では延べ床面積に対して必要とされる部材の数が少 ないため初期建設費が面積に対して低くなる傾向があるが、LCC 費 用としてみるとこの傾向がさらに拡大することがわかる。

\section{2. 経営期間別}

経営期間を 20 年から 80 年まで変えながら VI 指数の計算を行っ た結果を図 7に示す。建筑では 50 年から 65 年間の経営が最も合理 的であるが、設備では 20 年以下の経営が合理的である。

このことから、建物全体を合理的に長期間経営することを考える 場合、設備における長期的な効用を高めることが必要だといえる。

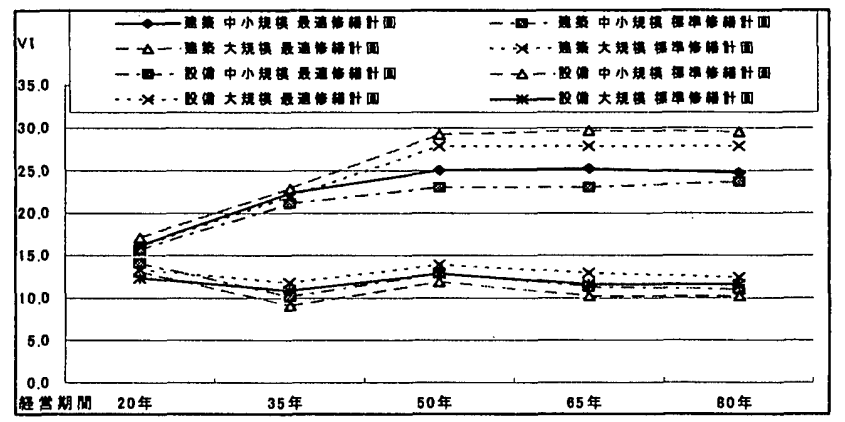

图 7 経営期間別 VI 指数

\section{6 結}

本研究では、建物の効用の判断に物理的要因のみではなく、社会 的要因、機能的要因を導入して分析を行った。その結果、オフィス ビルの修繥計画について以下の点が明らかになった。

1）現在行われている標準的な修纕計画に従って行われる修繥は、 最適な修繥計画に近く、費用対効用(VI)の雉点からの合理性が 認められる。

2）建築本体において修繥計画の合理性を改善するためには、標準 の修繥計画よりもこまめにメンテナンスすることが必要である。

3）設備において修繥計画の合理性を改善するためには、標淮的な 修繥計画よりもメンテナンス周期を長くできる可能性があるが、 運用にあたっては性能の低下に対する慎重な判断が必要になる と思われる。

4) VI から判断される合理的な経営期間は建築本体においては 50 年から 65 年であるが、設備では 20 年程度である。これから、 経営的な面から建物の長寿命化をはかるためには、設備におけ る長期的な効用を高めることが必要であると考えられる。

以上より、建物の長寿命化を考慮した経営を行うためには、少な くとも標準的な修繽計画として示されるものに見合った修繥・取替 費用をかけることで効用を維持することが必要であり、費用に対す る効用はメンテナンスをこまめに行うことでさらに问上することが できるといえる。

本稿では建物全体についての LCC に基づく修繥計画の分析に重 点を置いたため、計画・設計・施工の各段階で検討される材料の選 
定や修繥を実際に行う場合の問題点などについての分析は今後の㹎 題として残されている。建物の長寿命化を絽営的な面をふまえて検 討していくために、これらの点については、いずれ稿を改めて報告 することとしたい。

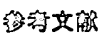

1）石塚兹高：建築物のライフサイクルコスト算定方法の開発、建築物のラ イフサイクルコスト算定に関する研究、日本建築学会計画系睮文報告集、 No.356、1985.10

2）高草木明 : 栠帒禀務所建物経営の収支計画に対応したライフサイクルコ ストに閔する研究、日本迠筑学会計画系睔立報告集、No.496、1997.6

3）小伀幸夫：建物害命の年龄別データによる推計に関する基磁的考察、日 本起築学会計画系論文報告集、No.439、1992.9

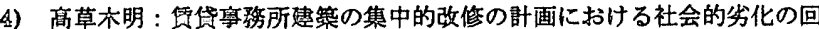
往人の投然評価に関する研究、日本建篹学会計画系踰文報告集、No.505、
1998.5

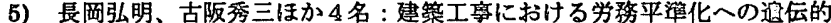
アルゴリズムの適用、日本建築学会計画系論文報告集、No.491、1997.1

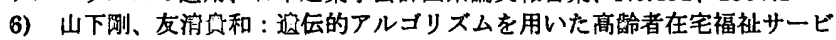
又供給の最適化手法試絮、日本建築学会計画系踚文報告集、No.509、1998.7 7) 守谷竐一、石坂公一、近江隆：オフィス・商黄系建物を想定した最適維 持管理計画の搎索手法、第 22 回悄報・システム・利用ジボジウム、1999.12

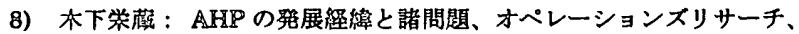
vol.44,No.1、1999.1

9) 加藤宽一郎：工学的最適制御、曺京六学出版会、1988

10) 北野宏明：進伝的アルジリズム、産恶图、1993

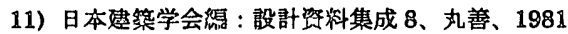

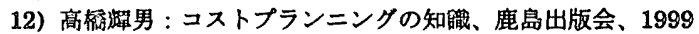

13）建設大臣官房官暯営䋹部監修 : 建築物のライフサイクルコスト、趽済調 鲁会、 1991

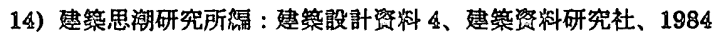

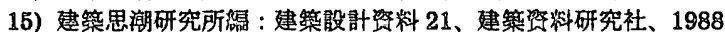

16) 石塚缕高 : 建築絽済学のす寸め、経済調查会、1994 